\title{
Heritage Management. The Natural and Cultural Divide
}

Heleen van Londen, University of Amsterdam - ACASA Department of Archaeology, Amsterdam, the Netherlands

Marjo Schlaman, University of Amsterdam - ACASA Department of Archaeology, Amsterdam, the Netherlands

Arkadiusz Marciniak, Adam Mickiewicz University in Poznań, Poland

In 2005, David Lowenthal commented on the dissimilar approaches to natural and cultural heritage and how these differences impact the protection and management of these heritages. His analysis touches on the western European perceptions of nature and culture that go back to the Age of Enlightenment. In his article, the motivation for safeguarding heritage stands out, as nature conservationists emphasize the long-term economic or ecological benefits, while cultural heritage managers point towards cultural or aesthetic benefits (Lowenthal 2005: 87). Others have made similar statements, some eight years later, calling the divide between the domains a fundamental error (Renes 2013; Harrison 2013).

Justifications why the natural and cultural divide should disappear in heritage management may vary. Regarding World Heritage sites, the IUCN and ICOMOS organized the Connecting Practice project $(2015 ; 2017)$ with the aim to explore the ways in which the interconnectedness of natural and cultural heritage can be best supported with the purpose of preserving both heritages in the landscape. Here, it seems that the complexity of landscape calls for effective managements strategies, forming the deeper motivation to interact. A sectoral heritage management practice may negatively impact the other domain, for instance through mowing, flooding, and deep-rooting species; or vice-versa, the removal of protected plants on cultural heritage monuments such as ruins or burial mounds. Tourism may impact the natural environment surrounding cultural heritage monuments, not only because of problems of mass, but also regarding facilities such as restaurants, parking places and hiking paths. Another example of justification is found in the ten-year research project Protection and development of the Dutch Archaeological-Historical Landscape and its European Dimension (20002010) (Bloemers et al. 2010). Many disciplines were brought together to study the issues and solutions to achieve sustainable development in reference to the European Landscape Convention (Bloemers 2010: 3). A third example is given by Harrison (Harrison 2015, 24), where is stated that now that the critique of separating natural and cultural heritage has been well established, the implications for cultural heritage management in this expanded field of integrated natural and cultural heritage management should be assessed. He advocates for the use of 'intertwined heritage', labelled as part and parcel of the Anthropocene, to serve wider societal issues, now and in the future. What follows is the overarching purpose that renders the nature-culture divide obsolete. There is no point in keeping the two domains separated, on the contrary, much to be gained when both are combined. In his argumentation, societal issues are presented as the logical driver for interdisciplinarity. All these above mentioned arguments resonate with the four primary drivers of interdisciplinarity defined by Klein (Klein 2010: 26). The author cites the typology of the National Academy of Sciences in the United States (2004), listing (1) the inherent complexity of nature and society, (2) the desire to 
explore problems and questions that are not confined to a single discipline, (3) the need to solve societal issues, and (4) the power of new technologies. The latter is gaining importance rapidly and can be expected to form additional arguments to lift the divide, for instance using the results of innovative remote sensing techniques.

The three reasons to overcome the longstanding divide between natural and cultural mentioned above, i.e. complexity, the broad exploration of problems and solutions and the societal issues as drivers for interdisciplinarity, run parallel to distinctive perspectives on heritage. As such, they form a relevant context to understand interdisciplinary aims and perceived benefits.

\section{Heritage perspectives and drivers for crossing boundaries}

Beginning in the second half of the 20th century, three modes of thinking can be discerned in which the discourse on the meaning of heritage for society has taken shape and form. Roughly, these modes can be characterized as 1) the Universal perspective and the intrinsic historical value of heritage (1970's - onwards); 2) the European perspective, heritage values relating to identity and memory (1990's - onwards); and 3) the Human Rights perspective, heritage value relating to well-being (2005 and onwards). These modes of thinking are not to be seen as consecutive phases, but rather as frames rooted in certain periods. Through time, extra strands have been added to the debate. The discourse then shows a certain time depth in which the meaning of concepts like ownership, stewardship and benefits are moulded. Strands are shared by communities and networks worldwide, and all three modes are coexisting. Especially the Human Rights perspective influences the current debate on heritage values.

\begin{tabular}{||l|l|l||}
\hline $\begin{array}{l}\text { European Meetings } \\
\text { Prior To Declarations }\end{array}$ & Place & Focus of the meeting \\
\hline 1969 st meeting & $\begin{array}{l}\text { Brussels, } \\
\text { Belgium }\end{array}$ & $\begin{array}{l}\text { The preservation and rehabilitation of the Cultural Heritage of } \\
\text { Monuments and Sites. European Convention on the Protection of } \\
\text { the Archaeological Heritage (European Treaty Series No.66). }\end{array}$ \\
\hline 1985 2nd meeting & $\begin{array}{l}\text { Granada, } \\
\text { Spain }\end{array}$ & $\begin{array}{l}\text { The protection and management of architectural heritage } \\
\text { Convention for the Protection of the Architectural Heritage of } \\
\text { Europe(European Treaty Series No.121). }\end{array}$ \\
\hline 1992 3rd meeting & $\begin{array}{l}\text { Valletta, } \\
\text { Malta }\end{array}$ & $\begin{array}{l}\text { The protection and management of archaeological heritage } \\
\text { European Convention on the Protection of Archaeological } \\
\text { Heritage (revised)(European Treaty Series No.143). }\end{array}$ \\
\hline 2001 5th meeting & $\begin{array}{l}\text { Felsinki, } \\
\text { Finland }\end{array}$ & $\begin{array}{l}\text { The political dimension of cultural heritage conservation in } \\
\text { Europe. Resolution No. 1 on the cultural heritage as a factor in } \\
\text { building Europe. Resolution No. 2 on the cultural heritage as a } \\
\text { factor of sustainable development }\end{array}$ \\
\hline 2015 6th meeting & $\begin{array}{l}\text { The cultural heritage and the challenge of globalization } \\
\text { Resolution No. 1 on the role of cultural heritage and the challenge } \\
\text { of globalisation. Resolution No. 2 on the Council of Europe's } \\
\text { future activities in the cultural heritage field, 2002-2005. } \\
\text { Declaration on the role of voluntary organisations in the field of } \\
\text { cultural heritage. Portorož declaration 2001. }\end{array}$ \\
\hline
\end{tabular}

Table 1: Overview of meetings leading to resolutions and declarations adopted at ministerial conferences of Ministers responsible for Cultural Heritage. 
The three modes are reflected in the declarations on heritage produced by the Council of Europe, and in issues that were on the agenda of meetings between European ministers responsible for cultural heritage. The titles of the declarations are telling. They go from protection of what is of value (1), to politics of identity (2) and well-being (3). The declarations have formed the basis of European Conventions and legal framework for member states. The last and most recent meeting was in 2015. The 2015 declaration aims for a well-being and a common European strategy based on unifying concepts like heritage and citizenship, society, economy, knowledge, territorial governance and sustainable development (Council of Europe 2015).

\section{The Universal perspective: integrating sectors}

The discussion on the value of heritage has been dominated in the early 1970s by the universalist position stating that heritage is of outstanding universal value and as such belongs to humanity as a whole:

"The cultural and natural heritage is among the priceless and irreplaceable assets, not only of each nation, but of humanity as a whole. The loss, through deterioration or disappearance, of any of these most prized assets constitutes an impoverishment of the heritage of all the peoples of the world. Parts of that heritage, because of their exceptional qualities, can be considered to be of 'outstanding universal value' and as such worthy of special protection against the dangers which increasingly threaten them." (UNESCO World Heritage Centre 1972a)

Outstanding Universal Value (OUV) is defined in the guidelines of the UNESCO World Heritage Convention (UNESCO, World Heritage Centre 2019: 20) as

\section{"cultural and/or natural significance which is so exceptional as to transcend national boundaries and to be of common importance for present and future generations of all bumanity. As such, the permanent protection of this heritage is of the highest importance to the international community as a whole".}

Sites with OUV hold a perceived value that is undisputed and thoroughly researched by experts. State parties select sites to become listed as world heritage. Also, the protection and management of these values for future generations is predominantly state led. Most European member states organized their first protective legislation after the Second World War within the Universal perspective. In it, heritage is seen as a public interest. Arguments for proving the OUV of sites have been instrumental in nation-building (Labadi 2013). Sites were framed through state politics and institutions in national heritage narratives. Sites with OUV have essence; there is a belief in the intrinsic nature of these sites. Authenticity as a concept lies at its core. Authenticity, according to UNESCO, is related to the spirit and feeling of places (genius loci). In 1994, the Nara Document (ICOMOS 1994) on authenticity provided a dynamic revision, supporting a more relativistic stance. However, in practice the revision has had very little impact, the concept refers mostly to the 'originality' of the physical fabric and the condition of sites i.e. design, material, workmanship, and setting (Labadi 2013). For the success of preserving heritage for future generations it is thought critical to gain reliable knowledge not only from an academic élite and its dissemination through public outreach to those who lack heritage knowledge, but much broader (Holtorf 2007). Contributions of any given country towards global heritage should be questioned as to the universalistic and undisputed knowledge for the global audience (which is non-descriptive). To be objective, 
knowledge needs to come from multiple sources with the potential to be combined and/or integrated into heritage discourse. Experts have a substantial role in respect to determining Outstanding Universal Values. They are regarded as the only legitimate and credible agents for the identification of potential world heritage sites. Experts define methodologies to research those subjective qualities of sites (for instance Wells 2014).

Within the Universal perspective, the complexity of the landscape justifies crossing disciplinary boundaries, as it is in essence a part of the intrinsic value of that heritage. Crossovers serve the better protection of the site in its many facets as is illustrated above with the Connecting Practices project reports.

\section{The European perspective: identity and diversity as unifying concepts}

The Valletta Convention (1992) as well as the European Landscape Convention (2000) issued by the Council of Europe aim to consolidate the European identity. The motto 'Diversity in Union' stands for value of freedom, equal rights and solidarity (Pinxten et al. 2007). Heritage is seen as part of a shared European history, one of the many facets present in a diverse landscape. As such it relates to memory and meaning. Many studies were funded on the wealth of Europe's diverse Cultural Landscapes, for instance by funding programmes like Cost Action A 27 (2004-2008) Understanding Pre-industrial Structures in Rural and Mining Landscapes (COST Landmarks 2005).

The European Landscape Convention (ELC) of 2000 came into force in 2004, introducing a then new definition of landscape. According to the ELC landscape is

"an area, as perceived by people, whose character is the result of the action and interaction of natural and/ or human factors" (Council of Europe 2000: 9).

Each Party shall undertake "to recognise landscapes in law as an essential component of people's surroundings, an expression of the diversity of their shared cultural and natural heritage, and a foundation of their identity". Currently the following statement features on the Council of Europe website:

"As a reflection of European identity and diversity, the landscape is our living natural and cultural heritage, be it ordinary or outstanding, urban or rural, on land or in water." (Council of Europe 2019).

The objectives are well-being for all and sustainable development (Prieur 2006: 15). Nature and culture are since connected by definition. And this vital understanding has been adopted as such by many member states that integrated the convention in their national legislation and policies -thirty-nine out of forty-one countries have ratified the Landscape Convention. Within the European perspective, landscapes are seen as multi-faceted, as 'mosaics' incorporating all together social, economic, cultural and ecological features. Studying and managing the landscape then requires a broad scope of disciplines, not per se restricted to those dealing with nature of culture (Fairclough \& Van Londen 2010, 653). Researchers and heritage managers aim to define landscape character, managing change. The justification is sustainable development, steering away from the practice of protected and fenced off monuments. 


\section{The Human rights perspective: unifying through serving the public}

Within the past few decades, two major developments have taken place. Firstly, the placement of heritage within the context of human rights, and secondly, the growing influence of private enterprises in heritage protection. These can be viewed as the processes of democratization and liberalization. The direction is towards that of utilization and profit. Social values of well-being and justice are added to, or maybe replacing, the universalist position and identity frameworks (Hodder 2010). In the human rights discourse, issues are socially negotiated. Heritage within that context is no longer in the domain of experts, its use and function is decided by the people and for the people.

The Faro Convention (2005) defines heritage as a social value, in explicit reference to the declaration of human rights: Le droit au patrimoine (the right to heritage). The convention introduced a new social reference group for heritage construction: the heritage community that "consists of people who value specific aspects of cultural heritage which they wish, within the framework of public action, to sustain and transmit to future generations" (Dolff-Bonekämper 2010: 19). This convention differs from both the Valletta Treaty and the European Landscape Convention which deal with heritage or landscape itself, stating practical do's and don'ts (Fairclough \& Van Londen 2010). Before this convention, there have been other treaties aiming to link heritage to human rights (Jukiletho 2012). An example of this includes the Fribourg Declaration (2007), which recognizes culture as the meta-structure of any civilization. The right to cultural heritage, embedded in the right to participate in cultural life, has to be associated with other basic needs such as the right to shelter, food, clothes, security and love (Dolff-Bonekämper 2010).

Although these linkages are clear to some, it is not widely shared by heritage practitioners who view conservation work as a technical matter (Logan 2012) or who act within a different paradigm, that of safekeeping (Van Londen 2016). Cultural diversity, cultural heritage, and human rights are the three central concepts for this discourse that should be regarded as related. Heritage identification, inscription, managing and monitoring are to be understood as a cultural practice (Logan 2012; Byrne 2008).

The purpose of linking heritage to human rights is to ensure safety, well-being and freedom for minorities and vulnerable groups (Sen 1985). Political and civil freedoms that include citizens, whose voices are being heard, is instrumental to the role of democracy and human rights (Sen 1999). This insight has also led to the association of heritage to human rights, where people have many different identities and freedoms that depend on respecting all individuals. Heritage is therefore intertwined with politics, identity and territory. In many cases, this has resulted in conflict and violence with various scales of impact (Silverman \& Ruggles 2007). Minorities, certain ethnic or religious groups may get outcasted when dominant parties forcefully use a single identity to define the norm (Sen 2007).

The list of human rights issues range from civil and political, to cultural and environmental, which includes climate change (OHCHR 2016). Both directly and indirectly, the adverse impacts of climate change threaten human rights throughout the world, including the rights to water and sanitation, food, health, housing, culture and education (OHCHR 2016). Climate change affects the environment and poses a threat to vulnerable ecosystems and isolated communities. Climate change and human rights are often debated in terms of environmental actions, where cultural values are displaced. It is why heritage allows for human rights. 
Nevertheless, the inclusion of cultural heritage in the climate change discourse is necessary, and reinforces the international community's obligation to take mitigation activities (Maus 2014). World Heritage Sites may be at risk due to climate change. For example, the Palace of Westminster and the Tower of London are threatened as the Thames Barrier in London was created to protect land and property against flooding, but due to the estimated rise in sea level, between $0.26 \mathrm{~m}$ and $0.86 \mathrm{~m}$ higher on average by 2080 (UNESCO World Heritage Centre 2008), the sites will be affected. Changes to both tangible and intangible heritage caused by climate change cannot be separated from changes in society, communities' behaviour, demographics, conflicting societal values and land-use planning (UNESCO World Heritage Centre 2008). Another example concerns local communities, who reside in the Artic, on low-lying island states or in coastal regions, facing serious loss of their lands and territories that are linked to social and cultural identity, beliefs and transmission practices inherent to their human rights (Maus 2014). In some cases, preservation itself could be turned against peoples' rights due to oppressive policies that reinforce economic disadvantages with rhetoric about cultural continuity, heritage, and characterisation of the poor as "traditional" and "living in the past" (Pyburn 2007). A shift in focus from a heritage-driven discourse towards a human rights-driven one, puts under the spotlight the people who may contribute to protect cultural heritage and the social structures and cultural processes that underlie this relationship. In addition, a cultural-rights-based approach to climate change may contribute to the imposition of an extra layer of obligation of governments in their fight against it (Maus 2014).

Within the human rights perspective, interdisciplinarity is the logical way forward to serve societal issues like civil rights, well-being, climate change and other great challenges society faces. Crossovers are not restricted towards natural and cultural heritage domains, but include domains like politics, health and economy.

While the perceptions, aims and benefits may differ, all three frames welcome mixing disciplinary concepts, methods and practice, albeit for intrinsic heritage value, sustainable development of the landscape or solving societal issues.

\section{Multi- and interdisciplinarity}

Before turning to the practice itself, it is worthwhile to elaborate further on the taxonomy of interdisciplinarity. Not all types of disciplinary combinations are per se interdisciplinary. And it does not have to be. The taxonomy relates to methods of crossovers and therefore helps to understand practice. The concept of interdisciplinarity itself can be perceived as vague. For this purpose definitions and concepts in this issue are drawn from the Oxford bandbook of interdisciplinarity (Frodeman et al. 2010).

Integration of disciplines is the determinant factor of interdisciplinarity. Also, degrees of disciplinary interaction may count as such. New knowledge, methods and concepts may arise. In contrast, multidisciplinary approaches juxtapose disciplines to offer broader insights, while disciplines do not alter in any way. Looking at a similar topic from different views is multidisciplinarity (Klein 2010: 17-24). These views can be ordered as a sequence or be coordinated when aligned. Because intercommunication is lacking, this type of practice is thought of as weak. Using information from one domain in another, for instance using history to create an historical context in an archaeological analysis, is also a multidisciplinary method. When existing methods are restructured through explicit focusing and blending 
this may results in a new approach. Comparable disciplines can form what is called a narrow interdisciplinarity, as opposed to broad practice such as the humanities and the sciences. They have little in common, so other disciplines may be brought in. Following this categorization, if natural and cultural heritage management were to be integrated, this would classify as a broad or wide interdisciplinarity. And, other disciplines, for instance from social sciences or earth sciences may be added to the combination.

Integration may occur on theoretical or methodological levels. The latter is chosen to improve results, for instance by borrowing a method from a different domain. Theoretical integration alters the general frame of thinking and therefor creating room for new types of analysis. To help understand the origins of the sectoral divide as Lowenthal showed, is a form of deconstruction that will help adopt wider frameworks of thought (Lowenthal 2005).

Integration may come in two forms using the metaphors of bridge building and restructuring. Bridge building can occur between two firm and complete disciplines, while restructuring uses only parts of a discipline.

Transdisciplinary practice stands apart from the multi- and interdisciplinary practice all together, as it cuts through the academic, policy and public domain, such as citizen science projects or the integration of lay knowledge in scientific output (Tress et al. 2003; Van Londen 2004). This type of practice is advocated under the Human Rights Perspective. Socalled Faro-projects emphasize public participation. Technological innovations propelled by the use of Internet help communities to act more independently.

\section{Modes of interaction}

What crossing boundaries really means in practice remains the challenge to be explored as posed by Harrison. He stresses the similarities of heritage processes and aims that offer room for interaction (Harrison 2015). Other publications advocate practical guidelines, for instance for the management of World Heritage sites (Leitão et al. 2017) or - a Dutch example - bringing cultural heritage management into the scope of nature development of brooks (Bleumink \& Neefjes 2017). Also, the integration of heritage into agricultural policy is put forward (Raap 2015).

The aim of this special issue is to reflect on an integrative heritage approach within this new framework. Various contributions illustrate the need for- and benefits or restraints of - a cross-over. The papers collected in this issue stem from a session focusing on the integration of natural and cultural heritage management held at the European Association of Archaeologist (EAA) conference in Maastricht, Building Bridges (Session 302 Integrating natural and cultural heritage. Internal coherence and external efficiency), The conference session was one of the outputs of the Erasmus plus project Innovative format of education and training of the integrated archaeological and natural heritage (ANHER Erasmus plus project 2014-1-PL-KA202-003565) aimed at producing e-learning modules on the theme (Teaching Heritage 2017).

The first contribution by Bas Pedroli offers an academic perspective on theoretical integration by using an anthropological analogy. In his paper Natural heritage management, or is it cultural heritage after all? Towards new commons and sharing interests in the landscape the author questions the western way of interpreting landscape. His conceptualization of landscape is indeed a mosaic of varies facets as is advocated by the European Landscape Convention. The second article 
by Emmet Byrnes, Karl Cordemans and Cees van Rooijen is an international evaluation of the impact of the common EU agricultural policy on archaeological heritage. These EU experiences are accompanied by an evaluation from the United States by Jeff Altschul and Michael Heilen. Both contributions focus on the devastating effect of nature management on cultural heritage, calling on the intrinsic value of heritage. The authors have looked into policy practice and stress the importance of an immediate and combined approach to stop current devastating ways of management. Theirs is an activist analysis bringing forward a clear message, where the focal point is the relations between politicians, policy makers and experts. The following three contributions introduce the wider public as a variable in the equation natural/cultural heritage management. Åsa Ahrland presents as case study the new business model introduced in Sweden that promotes the integration of natural and cultural heritage. In particular, she illustrates the potential that collaborations with the private sector may have. Kornelia Kajda describes a Polish case study on a heritage discourse in society combining expert and public knowledge in a grim setting relating to identity politics. Andrea Travaglia focuses on heritage and crowd-based initiatives regarding the new environmental act in the Netherlands. She contextualizes democratization processes in policy. This section on public engagement is followed by pragmatic approaches. Heleen van Londen offers four practical ways to engage in interdisciplinary cooperation, while Marjo Schlaman stresses the merits of disciplinary work, asking herself whether integration is always a good idea. The volume concludes with an agenda for the future by Arkadiusz Marciniak.

This volume contributes to the ongoing discourse regarding the natural and cultural divide with a broad perspective that includes an academic, policy and societal point of view. It has aimed for both conceptual as practical approaches to the topic, as well as the motives for crossovers such as safeguarding and active contributions to broader societal issues. These motivations resonate with current paradigms in heritage management.

\section{References}

Bleumink, H \& J. Neefjes, 2017. Handboek Beken en Erfgoed. Beeklandschappen met karakter. Stichting Toegepast Onderzoek Waterbeheer in samenwerking met de Rijksdienst voor het Cultureel Erfgoed.

Bloemers, J.H.F., Kars, H., van Der Valk, A., \& Wijnen, M., (eds), 2010, The cultural landscape \& heritage paradox: protection and development of the Dutch archaeological-historical landscape and its European dimension. (Landscape \& heritage series). Amsterdam: Amsterdam University Press Byrne, D., 2008. Heritage as social action, in: G. Fairclough Et Al. (eds), The heritage reader. London: Routledge, 149-173.

Cost Landmarks 2005. Accessed 6 October 2019. https://www.cost.eu/publications/costaction-a27b-landmarks/.

Council of Europe Landscape Convention 2000. Accessed 11 June 2019. https://www. coe.int/en/web/landscape

Council of Europe 2015, High-level Conference on the "Implementation of the European Convention on Human Rights, our shared responsibility, at the initiative of the Belgian Chairmanship of the Committee of Ministers of the Council of Europe, 27 March 2015.

Council of Europe Landscape Convention 2019. Accessed 11 June 2019, https://www. coe.int/en/web/landscape/home.

DolfF - Bonekämper, G., 2010. Cultural Heritage and Conflict: the view from Europe, in Museum International 62 (1-2), 14-19. 
Fairclough, G., \& van Londen, H., 2010. Changing landscapes of archaeology and heritage, in: T. Bloemers, H. Kars, A. van der Valk, \& M. Wijnen (eds), The cultural landscape \& heritage paradox: protection and development of the Dutch archaeological-historical landscape and its European dimension. (Landscape \& heritage series). Amsterdam: Amsterdam University Press, 653-669.

Frodeman, R., Klein, J. T., \& Mitcham, C., (eds), 2010. The Oxford handbook of interdisciplinarity. Oxford. Hodder, I., 2010. Cultural Heritage Rights: From Ownership and Descent to Justice and Well-being. Anthropological Quarterly 83, no. 4: 861-882. Accessed July 11, 2018.

https://muse.jhu.edu/.

Holtorf, C., 2007. Can You Hear Me at the Back? Archaeology, Communication and Society. European Journal of Archaeology, 10 (2-3): 149-165.

ICOMOS, 1994, The Nara document on Authenticity. Accessed October 29, 2019. https://www.icomos. org/charters/nara-e.pdf.

KLEIN, J. T., 2010. A taxonomy of interdisciplinarity. The Oxford Handbook of Interdisciplinarity, 15-30.

JokileHto, J., 2012. Human rights and cultural heritage. Observations on the recognition of human rights in the international doctrine. International Journal of Heritage Studies, 18:3, 226-230, DOI: 10.1080/13527258.2012.651741.

LABADI, S., 2013. UNESCO, cultural heritage and outstanding universal values. value-based analyses of the World Heritage and Intangible Cultural Heritage Conventions. Latham: Alta Mira Press.

Leitão, L., Bourdin, G., Badman, T. \& Wigboldus, L., 2017. Connecting Practice Phase II: Final Report. Project Report. ICOMOS/IUCN.

LogAN, W., 2012. Cultural diversity, cultural heritage and human rights: towards heritage management as human rights-based cultural practice. International Journal of Heritage Studies, 18:3, 231-244. DOI: 10.1080/13527258.2011.637573.

LONDEN, H. van, 2004. Cultural biography and the power of image, in: W. van DER KNAAP \& A. vAN DER VALK (eds), Multiple Landscape, merging past and present, Wageningen University, 171-181.

Londen, H. van, 2016. Archaeological Heritage Education and the Making of Regional Identities', in C. Boxtel, M. Grever \& S. Klein (eds), Sensitive Pasts. Questioning Heritage in Education. Berghahn Books, 153-170.

LowentHAL, D., 2005. Natural and cultural heritage, International Journal of Heritage Studies, 11:1, 81-92. DOI: 10.1080/13527250500037088, https://doi.org/10.1080/13527250500037088.

Maus, S., 2014. Hand in hand against climate change: cultural human rights and the protection of cultural heritage. Cambridge Review of International Affairs, 27:4, 699-716.

RaAp, E., 2015. Visie Erfgoed en Ruimte, programmalijn Levend Landschap. Amersfoort: Rijksdienst voor het Cultureel Erfgoed.

RENES, J., 2013. Natuur en landschap op zoek naar een nieuw verbond, printed paper 12.06.2013.

OHCHR, 2016. Report of the Special Rapporteur on the Issue of Human Rights Obligations Relating to the Enjoyment of a Safe, Clean, Healthy and Sustainable Environment: Climate Change Report (February 1, 2016), United Nations Human Rights Council, A/HRC/31/52.

Pinxten, R., Cornelis, M. \& Rubinstein, R. A., 2007. European Identity: Diversity in Union, International Journal of Public Administration, 30:6-7, 687-698. DOI: 10.1080/01900690701216092

Prieur, M., 2006.Landscape and social, economic, cultural and ecological approaches, preamble to the convention, Council of Europe, Landscape and sustainable development: challenges of the European Landscape Convention, 15. https://rm.coe.int/16804895e6.

Pyburn, K., 2007. Archaeology as Activism, in: H. Silverman and D. F. Ruggles (eds) Cultural Heritage and Human Rights. Springer, 172-183.

SEN, A., 1985. Commodities and Capabilities. Amsterdam.

Sen, A., 1999. Development as freedom (1st ed.). New York: Oxford University Press. 
Teaching Heritage 2017. Accessed 29 October 2019. http://e-archaeology.org/teachingheritage/

Tress, B., Tress, G., van Der VAlK, A. \& Fry, G., (eds), 2003. Interdisciplinary and Transdisciplinary Landscape Studies: Potential and Limitations. Wageningen: Wageningen University.

Silverman, H. \& Ruggles, D. F., (eds), 2007. Cultural Heritage and Human Rights. Springer.

UNESCO, 1972, Convention Concerning the Protection of the World Cultural and Natural Heritage, World Heritage Centre.

UNESCO, 2019, The Operational Guidelines for the Implementation of the World Heritage Convention, World Heritage Centre. Accessed 6-12-2019. http://whc.unesco.org/en/guidelines/

Wells, J.C., 2014. A Methodological Framework for Assessing the 'Spirit and Feeling' of World Heritage Properties, in: T. Gensheimer \& C.L. Guichard (eds) World Heritage and National Registers. Stewardship in Perspective, New Brunswick/London: Transaction Publishers, 19-33. 